\title{
North Bali Students' Online Learning Self-Efficacy, Engagement, and Satisfaction
}

\author{
Putu Dinia Suryandani, ${ }^{1 *}$ Made Hery Santosa ${ }^{2}$ \\ 1,2 Universitas Pendidikan Ganesha, Singaraja, Bali - Indonesia
}

\begin{abstract}
This study aimed to investigate the relationship among online learning self-efficacy, engagement, and students satisfaction in online learning. The design of this study was mixed-method research through surveys and open-ended interview with the purposive sampling technique. The quantitative data were analyzed using multiple regression. The respondents were 24 postgraduate students from North Bali, Indonesia. The quantitative data were analyzed using correlation and regression techniques, and an open-ended interview was conducted. The research results showed a positive correlation between online learning self-efficacy, engagement, and students' satisfaction. The study concludes that students' satisfaction can be enhanced by increasing students' online learning self-efficacy and engagement either individually or simultaneously. The implication of this study revealed that strategies in selfefficacy and engagement during learning-related emotions could play a mediating role in academic satisfaction Additionally, learning-related emotion impacts the metacognitive learning procedures, which thus intervene the impact of satisfaction in online learning.
\end{abstract}

Article Information

Received 20 August 2021

Accepted 28 September 2021

Published October 29, 2021

Keywords: engagement; online learning; satisfaction; self-efficacy

\section{Introduction}

Students' satisfaction is a significant indicator for determining the quality of online education. De Paepe, Zhu, \& Depryck (2018) stated that students' satisfaction significantly influences the dropout rates in higher education. They added that the greater level of students' satisfaction, the lower the dropout rate will be. Alqurashi (2019) mentioned that students' satisfaction determined the success of online learning. Students' satisfaction is related to various factors, including the degree

*Corresponding Author: Dinia Suryandani (dinia@undiksha.ac.id) Jimbaran, Kuta Selatan, Badung, Bali 80361 of assistance provided by the instructor, the instructor's efforts to make the online learning personalized, an approach that promotes student-centered activities, and the course's multimodal online delivery. Online learning is defined as educational instruction offered with components of synchronous learning. Online learning is seen to have several advantages compared with traditional classroom learning. However, not all learners can successfully participate in online courses. Several studies have mentioned self-efficacy and its contribution to academic success, especially in satisfaction with online learning 
(Doo \& Bonk, 2020; Jiwa, Tanduklangi, \& Sailan, 2017; Kreth, Spirou, Budenstein, \& Melkers, 2019; Lin, Hu, \& Chiu, 2020). In addition, students' engagement is also regarded as a factor that influences students' satisfaction in online learning (Gray \& DiLoreto, 2016; O'Flaherty \& Phillips, 2015; Wolverton, Guidry Hollier, \& Lanier, 2020).

Through such practice, students would get active mastery experience, which is the essential source of self-efficacy (Lin et al., 2020). Also, the classroom should be a learning atmosphere for students. Environmental influences impact people's behavior, and cognitive processes could add to learners' selfefficacy (Bandura, 1977) because it affects students' motivation and learning, self-efficacy appears to be important in student learning., self-efficacy influences students' performance and learning behavior in task selection, effort, perseverance, and performance in terms of the relationship between internal personal variables and behavior (Panadero \& Alonsotapia, 2014). Furthermore, self-efficacy promotes motivation and cognition during the learning process by influencing students' task interest, task perseverance, goal setting, choice-making, and learning strategies.

Buelow, Barry, \& Rich (2018) suggested that students' engagement is critical regardless of how a course is delivered. Students' engagement is described within three aspects: behavioral, affective, and cognitive (Skinner \& Pitzer, 2012). Students' satisfaction and course completion are dependent on engagement (Wolverton et al., 2020) and refer to the level of effort students put forth to perform successfully and achieve their goals. Any university's goal is to improve students' satisfaction while reducing dissatisfaction, hence improving the institution's performance. Engagement and disaffection dictate the intensity and quality of effective participation in lessons. Students that are interested in learning activities try to internalize their tasks by exerting more significant effort and being more careful. Affectively, these pupils exhibit pleasure, interest, and enjoyment when working on intellectual activities (Buelow et al., 2018). In terms of cognition, these pupils make more motivated efforts, employ more methods, and do not appear to be preoccupied with activities. Dissatisfied students may attempt to complete activities in a distracted manner. While preoccupied with academics, they suffer negative affective experiences such as boredom, anxiety, and fatigue.

Moreover, as the growth of online learners in higher education is improving every year, the factors contributing to students' satisfaction in learning are highly needed. This present study aimed to investigate the complex relationship between several variables reflecting students' satisfaction, a set of indicators of student engagement, and their self-efficacy with online learning events. The setting of this examination was in a university in North Bali, which implemented full Online Learning due to the Covid-19 pandemic. A few postgraduate program students surrender too early, and some have to submit tasks late. The reason could be that they come from various backgrounds, ages, and expectations in acquiring the master's degree, which can affect their selfadequacy, commitment, and fulfillment in 
adapting, particularly during the pandemic $100 \%$ of the learning conducted online. The preliminary observation and interviews demonstrate that a portion of the postgraduate students has issues in adjusting to internet learning. Individual and ecological elements influence each other. Students with high self-efficacy and engagement may view the assignment as a test and work diligently to master it, producing a positive learning atmosphere in the process. Conversely, those with low self-efficacy and engagement may try to avoid the task, disrupting their learning. Thus, the purpose research was to find out the relationships between online learning self-efficacy, engagement, and students' satisfaction among postgraduate students in North Bali and what determines student (dis)satisfaction in online learning.

\section{Method}

This study used a mixed-method design (Creswell, 2009). Two independent variables (online learning self-efficacy (X1) and engagement (X2)) and one dependent variable (students' satisfaction $(\mathrm{Y})$ ) were examined. This study was conducted on 24 first-year postgraduate students (22 females and 2 males) at a university in North Bali. The respondents were chosen based on the purposive sampling technique. These students have learned fully online because of the Covid-19 pandemic. In addition, the postgraduate students come from different ages, backgrounds, and motivations in taking the enrollment. Later, the students were guaranteed that their information would be kept private. All of the students provided written informed consent before the start of the study. They were instructed to complete the forms anonymously. The study's participation was entirely optional, and those who agreed to take part completed the questionnaires. The students were given questionnaires and asked to respond to questions on their experiences with these emotions throughout the semester. In addition, online learning self-efficacy, engagement, and satisfaction surveys were delivered at the same time.

Quantitatively, data were collected using an instrument in the form of a questionnaire with a five-point Likert scale. The online learning self-efficacy scale (OLSES) developed by Zimmerman and Kulikowich (2016) was used to measure the students' online learning self-efficacy (22 items). Students' engagement was measured by using the Student Engagement Course Questionnaire (SECQ) developed by Handelsman et al. (2005). Student Engagement Course Questionnaire (SECQ) has 22 items. In addition, the students' satisfaction questionnaire used was 23 items of General Satisfaction of Students in $100 \%$ Online Courses developed by Ahn (2013). The instruments used in this study were reported as valid and reliable, which they have been used in many studies. The Cronbach's Alpha of each instrument was calculated statistically to measure the reliability of the instrument. The reliability coefficients of instruments have been displayed in Table 1. 
Table 1

Reliability coefficients of data collection tools

\begin{tabular}{lll}
\hline Scale & Cronbach's Alpha & $\mathbf{N}$ (Items) \\
Online Self-efficacy & .952 & 22 \\
\hline Students Engagement & .98 & 23 \\
\hline Students' satisfaction & .983 & 23 \\
\hline
\end{tabular}

Kalaycı (2009) stated that depending on Cronbach's Alpha coefficient value if $0.80 \leq \alpha<$ 1.00 , the scale is highly reliable, showing that all three instruments were highly reliable scales. Therefore, these values demonstrated that the instruments were valid and reliable. Finally, an unstructured interview was conducted to obtain deeper information related to factors in determining students' satisfaction. The validity of the instruments was determined by the value for each relationship, which was more than 0.3. In addition, to get more in-depth information, an open-ended interview was conducted. The interview questions were about the postgraduate students' perspectives on their online learning self-efficacy, engagement, and satisfaction with online learning.

Statistical analysis in this study was conducted to test research hypotheses that have been proposed by using Statistical Package for the Social Sciences (SPSS) 19.0 version. Data were analyzed descriptively and inferentially. The descriptive analysis consists of presenting data with mean and standard deviation to determine each variable's level. Inferential analysis or hypothesis testing were examined using correlation and regression analysis. Correlation consists of simple correlations and multiple correlations. Regression consists of simple regression and multiple regression. The data obtained were analyzed by simple correlation to determine the close relationship of each variable $\mathrm{X}$, and $\mathrm{Y}$. Simple regression was used to examine the relationship of each variable $X$ and $Y(X 1$ and $X 2$ with $Y$ ). Multiple correlations were used to determine the close relationship between $X 1$ and $\mathrm{X} 2$ variables together with $\mathrm{Y}$. In addition, multiple regression was used to determine the contribution of $\mathrm{X} 1$ and $\mathrm{X} 2$ variables together with $\mathrm{Y}$.

A semi-structured interview was adopted to obtain additional qualitative data to make conclusions. The participants were asked to share their experiences with the online learning environment and the obstacles they faced, and the techniques they used to overcome them. In addition, interview data were shown to determine dynamic relations between students' self-efficacy, engagement, and satisfaction. The interview results indicate the general sense of satisfaction in online learning and students' beliefs in one's learning.

\section{Findings and Discussion}

\section{Testing Data Analysis Requirements}

Testing of prerequisite analysis was conducted before the data analysis. The test involved normality test, multicollinearity test, heteroscedasticity 
test, autocorrelation test, and hypothesis testing (F-test and T-test).

\section{Normality Test}

The normality test was performed because the data analysis in this study used regression and correlation analysis. At the same time, the independent variable data and the dependent variable must be normally distributed. The result of the normality test is displayed in Table 2.

Table 2

The Normality Test Result

One-Sample Kolmogorov-Smirnov Test

\begin{tabular}{lll}
\hline & & Unstandardized Residual \\
\hline Normal Parameters & & 24 \\
\hline Most Extreme Differences & Mean & .0000000 \\
\cline { 2 - 3 } & Std. Deviation & 7.13484646 \\
\cline { 2 - 3 } & Absolute & .244 \\
\cline { 2 - 3 } & Positive & .244 \\
\cline { 2 - 3 } & Negative & -.166 \\
\hline Kolmogorov-Smirnov Z & & 1.195 \\
\hline Asymp. Sig. (2-tailed) & & .115 \\
\hline a. Test distribution is Normal. & \\
b. Calculated from data. &
\end{tabular}

The data show that the significant value of the three variables is 0.115 and is greater than $0.05(0.115>0.05)$. Thus, it can be concluded that the residual value is normally distributed because it accepts $\mathrm{HO}$ and rejects $\mathrm{H} 1$.

\section{Multicollinearity Test}

\section{Table 3}

Multicollinearity Test

\section{Coefficients}

\begin{tabular}{|c|c|c|c|c|c|c|c|c|}
\hline \multirow[b]{2}{*}{ Model } & & \multicolumn{2}{|c|}{$\begin{array}{l}\text { Unstandardized } \\
\text { Coefficients }\end{array}$} & \multirow{2}{*}{$\begin{array}{l}\text { Standardized } \\
\text { Coefficients } \\
\text { Beta }\end{array}$} & \multirow[b]{2}{*}{$\mathrm{t}$} & \multirow[b]{2}{*}{ Sig. } & \multicolumn{2}{|l|}{$\begin{array}{l}\text { Collinearity } \\
\text { Statistics }\end{array}$} \\
\hline & & $B$ & Std. Error & & & & Tolerance & VIF \\
\hline \multirow[t]{3}{*}{1} & (Constant) & -.778 & 10.963 & & -.071 & .944 & & \\
\hline & $\begin{array}{l}\text { Self-Efficacy } \\
\text { (X1) }\end{array}$ & .514 & .171 & .439 & 3.000 & .007 & .468 & 2.138 \\
\hline & $\begin{array}{l}\text { Engagement } \\
\text { (X2) }\end{array}$ & .502 & .142 & .516 & 3.526 & .002 & .468 & 2.138 \\
\hline
\end{tabular}

Table 3 displays that the symptoms of multicollinearity Tolerance value of online learning self-efficacy (X1) and engagement (X2) are $>0.1$ and VIF values are $<10$, which means 
that there is no connection between the independent variables. Thus, multicollinearity assumptions are met (free of multicollinearity).

\section{Heteroscedasticity Test}

Heteroscedasticity is helpful in determining whether the residual variance of one observation period differs from that of another. Glejser Test was utilized in this investigation to see if a model was free of heteroscedasticity. The result of the Glejser Test is displayed in Table 4.

Table 4

Heteroscedasticity

\begin{tabular}{|l|l|}
\hline Model & Sig. \\
\hline $\mathrm{X} 1$ & 0.087 \\
\hline $\mathrm{X} 2$ & 0.122 \\
\hline
\end{tabular}

From the table above, the result of significant value for independent variables online learning self-efficacy (X1) and engagement (X2) with dependent variable

\section{Autocorrelation Test}

The Durbin-Watson statistics is displayed in Table 5.

heteroscedasticity.

\section{Table 5}

Durbin-Watson Autocorrelation

\begin{tabular}{llllll}
\hline Model & R & R Square & Adjusted R Square & Std. The error of the Estimate & Durbin-Watson \\
\hline 1 & $.889^{\mathrm{a}}$ & .79 & .77 & 7.467 & 1.663 \\
\hline
\end{tabular}

a. Predictors: (Constant), Engagement (X2), Self-Efficacy (X1)

b. Dependent Variable: Satisfaction (Y)

The Durbin-Watson statistics of two variables $\mathrm{X}$ with 24 respondents above shows that $\mathrm{dl}=1.188$ and $\mathrm{du}=1.546$. The value of Durbin-Watson is 1.663 . The result is $1.546<$ $1.663<2.454$, indicating that the data is free from autocorrelation.

\section{Hypothesis Testing}

The F-test and the t-test are two types of hypothesis testing. The simultaneous effect is determined using the F-test, and the partial effect of each independent variable on the dependent variable is determined using the Ttest.

\section{Simultaneously Test (F-test)}

A simultaneous test was conducted to determine whether online learning self-efficacy (X1) and engagement (X2) have a simultaneous 
Table 6

Anova $^{\mathrm{b}}$

\begin{tabular}{lllllll}
\hline Model & & Sum of Squares & df & Mean Square & F & Sig. \\
\hline 1 & Regression & 4394.995 & 2 & 2197.497 & 39.414 & $.000^{\text {a }}$ \\
& Residual & 1170.839 & 21 & 55.754 & & \\
& Total & 5565.833 & 23 & & & \\
\hline
\end{tabular}

a. Predictors: (Constant), Engagement (X2), Self-Efficacy (X1)

b. Dependent Variable: Satisfaction (Y)

The significant value of F-Count is 0.000 . The sig is less than 0.05, which means the confidence of this prediction is above $95 \%$, and the probability of this prediction error is below $5 \%$, which is 0.000 . It means that online learning self-efficacy (X1) and engagement (X2) influence students' satisfaction simultaneously.

\section{Partially Test (T-test)}

The correlations between the independent variables and students' satisfaction are displayed in Table 7.

\section{Table 7}

Correlations between the independent variables and student satisfaction

\section{Satisfaction \\ (Y) \\ Self Efficacy (X1) \\ Engagement \\ (X2)}

\begin{tabular}{lllll}
\hline \multirow{2}{*}{$\begin{array}{l}\text { Pearson } \\
\text { Correlation }\end{array}$} & Satisfaction (Y) & 1 & 0.816 & 0.836 \\
\cline { 2 - 5 } & Self Efficacy (X1) & 0.816 & 1 & 0.73 \\
\cline { 2 - 5 } & Engagement (X2) & 0.836 & 0.73 & 1 \\
\hline
\end{tabular}

From the table above, it is known that online learning self-efficacy was positively related to students' satisfaction. The Pearson correlation value $(r)$ is $0.816, p<.005$ with sig. (1-tailed). The engagement variable (X2) is also showing a significant correlation with students' satisfaction variable $(Y), r=0.836, p<.5$ with Sig. (1-tailed). It indicates that students who are highly engaged in online learning tend to significantly be satisfied.

\section{What determines student (dis)satisfaction in online learning?}

An open-ended interview was conducted to answer the second research question. The questions are related to their experience in online learning, such as factors that make them more engaged in the activities, their level of confidence in completing the task, and aspect of online learning which make them satisfied or dissatisfied. The results are presented in Table 6. 
Table 8

Results of Interview

\begin{tabular}{|c|c|c|}
\hline Instrument & $\begin{array}{l}\text { Item } \\
\text { Number }\end{array}$ & Answer \\
\hline \multirow[t]{4}{*}{$\begin{array}{l}\text { Online } \\
\text { Learning Self } \\
\text { Efficacy }\end{array}$} & 2 & $\begin{array}{l}\text { "I never used any hard-copy of books to complete a task; instead, I } \\
\text { only used online books or other relevant studies through the } \\
\text { Internet. Besides, I can get unlimited sources; it is also cheaper". }\end{array}$ \\
\hline & 4 & $\begin{array}{l}\text { "To be honest, I feel more confident in doing meetings through } \\
\text { zoom meeting or google meet rather than meeting in person." }\end{array}$ \\
\hline & 6 & $\begin{array}{l}\text { "Sometimes it is hard to deal with the technical problem on my } \\
\text { own; I'd rather pay some money and let the technician service do it, } \\
\text { like when my laptop is broken." }\end{array}$ \\
\hline & 8 & $\begin{array}{l}\text { "In addition to be the students, I am also a mother, a part of society, } \\
\text { and a teacher. Therefore, I find it hard when I have to complete the } \\
\text { task in time, but I also do not want to be late; it is hard for me to } \\
\text { manage the time efficiently." }\end{array}$ \\
\hline \multirow[t]{3}{*}{$\begin{array}{l}\text { Students } \\
\text { Engagement }\end{array}$} & 5 & $\begin{array}{l}\text { "I never want to miss any meetings. I always make time to do things } \\
\text { because I do not want to be left behind". }\end{array}$ \\
\hline & 9 & "I always take a note if the lecturer gives feedback and suggestion." \\
\hline & 17 & $\begin{array}{l}\text { "Reading is not my hobby; I see reading as my responsibility. That is } \\
\text { why when other responsibilities coming up, it is hard to stay up on } \\
\text { the reading." }\end{array}$ \\
\hline \multirow[t]{3}{*}{$\begin{array}{l}\text { Students' } \\
\text { satisfaction }\end{array}$} & 2 & $\begin{array}{l}\text { "The lecturers are always ready anytime to clarify things I am } \\
\text { confused about. Their feedbacks are valuable, which I can use for } \\
\text { further learning." }\end{array}$ \\
\hline & 5 & $\begin{array}{l}\text { "I am satisfied that the project or assignment provided by the } \\
\text { lecturers improves my creativity and makes me critical; it makes me } \\
\text { go from my comfort zone." }\end{array}$ \\
\hline & 23 & $\begin{array}{l}\text { "Online learning is much different with offline learning; in offline } \\
\text { learning, we can see the real struggle our fellows have, and the } \\
\text { discussion certainly becomes alive." }\end{array}$ \\
\hline
\end{tabular}


The above results show that students' satisfaction increases if their online learning self-efficacy is high. This result is consistent with Zimmerman \& Kulikowich (2016). Kreth et al. ( 2019) found that pre-existing knowledge of self-efficacy of students is the most vital element in describing a good impression of the online learning environment. They stated that self-efficacy had the most influence on characterizing learning process expectations compared to demographics or human capital measures. The nature of the social institution to which the students belong to can also provide familiar support. This study found that resilience fully mediates the association between self-determination and self-efficacy, confirming the prediction. It suggests that, through the mediation of resilience, being selfdetermined boosts one's self-efficacy. Student achievement, satisfaction, and the likelihood of women persevering in male-dominated fields are all indicators of learning self-efficacy. Moreover, these findings are also in line with Hong, Hwang, Tai, \& Lin, (2017), who found that higher self-efficacy or intrinsic motivation predicts better learning achievement, which fosters even more self-efficacy or intrinsic drive self-efficacy in peer assessment activities.

The engagement also shows a significant correlation with students' satisfaction. This indicates that students who are highly engaged in online learning tend to be significantly satisfied. The results are consistent with previous studies (Gray \& DiLoreto, 2016; Muzammil, Sutawijaya, \& Harsasi, 2020). Unlike traditional face-to-face classroom learning guided by a teacher, online learning relies on the Internet and the development of information technology, as well as learning systems through online and multimedia interactions (Malmberg, Järvelä, Järvenoja, \& Panadero, 2015). However, while online learning has advantages such as time flexibility, learning independence, and the elimination of geographical barriers, it also has drawbacks such as reduced social interaction, high costs, tutorial requirements, technology access, and internet speed (Bower \& Sturman, 2015). To make a solid sense of community and to assist students in learning in online courses, teachers need to discover approaches to help students feel more emphatically associated with one another, with the educator, and with the subject learned, as well as to choose exercises which effectively include students in their learning.

Metacognitive awareness and multidimensional approaches have been shown in previous research to help students cope with online instruction more effectively (Morgan, 2019). When it comes to online learning, students' mean ranks have risen as their satisfaction with learning objectives, assessment plans, online platforms, webinars, and tutorials has increased (Landrum, 2020). As a result, the participants perceived the online learning platforms as experiential and constructive learning environments. The highest mean of items in the OLSES is item number four, "communicate effectively with technical support via email, telephone, or live online chat." A student interviewee stated that $s /$ he prefers online meetings to offline meetings. She also mentioned that her reason for enrolling herself in this postgraduate program was that it is online, so she can do other things simultaneously. The findings of this study revealed that learning benefits not only 
from a general sense of self-efficacy but also from a specific belief in one's language learning ability and perception of the possibility for academic success in online learning. The agentic engagement was a distinct and essential trait linked to learners' productive motivation, related to those three aspects of engagement, and recognized as an independent component in achievement ( $\mathrm{Yu}$, Wang, \& Spector, 2020). Its application in learning, which aids students in structuring their learning by modifying their lectures and study environment.

Students' involvements provide positive learning experiences, such as discussion in collaborative workgroups, presentations, conversations, resource sharing, task completion, and combining case studies with reflection. Students will have a more individualized learning experience if given options or some flexibility (Strawser, Kercsmar, \& Pennell, 2017). Students realized the advantages of online sources are beyond limitations. They believed that both soft-copy and hard-copy have the same function: to give insight to the readers. In terms of economy, online sources such as books and journal articles are much cheaper, so students can save more money. The sixth item in OLSES is one of the items that have the lowest mean. One student witnessed that she would spend more money to fix the technical problems rather than adding difficulties in her life by doing things she could not do herself. The OLSES lowest mean was the eighth item that most students find it hard to manage their time effectively. Postgraduate students have characteristics of coming from different backgrounds and priorities. Most of the respondents have jobs, while some have married and have children. Previous studies have shown that internet learning self-efficacy improves as there are expansions in the number of encounters and experiences with innovation. It usually follows that people with more noteworthy openness to various learning advances will have key computing skills essential for accomplishment in a web-based learning situation.

The engagement has a favorable impact on academic progress and enjoyment. Faculty and institutions in the field of distance education are always looking for ways to improve students' satisfaction (O'Flaherty \& Phillips, 2015). The remote education platform presents instructors and students with a unique set of issues; leading institutions endeavor to define and overcome these challenges to the benefit of all concerned parties. Also, researchers propose that openness to advanced learning innovations impacts technology self-efficacy and the scholarly accomplishment of online students, taking note of a move towards progress in more significant level abilities, for example, critical thinking and basic reasoning. However, students' perspectives towards internet learning can likewise affect their degrees of engagement. Students with more uplifting outlooks towards online learning conditions had a higher degree of self-efficacy in learning content in online settings. Next, communication appears to be a recurring theme in the literature, prompting both educators and institutions to take notice. Instructors give insights concerning course expectations, due dates, rules, assessment rubrics, and resources to work with students' scholarly achievement and supported learning. 
Also, the foundation of a course should be legitimately coordinated, easy to understand, and detailed about the student learning targets.

\section{Conclusion}

The findings revealed that all interaction patterns, including student online learning selfefficacy, positively affect students' satisfaction. The findings of this study are expected to demonstrate the implementation of online learning. Teachers are being introduced to effective learning strategies and tactics that will help students to explore pleasant accomplishments, experiences, and emotions in order to reduce disaffection in online programs. Furthermore, providing teachers with knowledge on the effects of self-efficacy beliefs on engagement might be beneficial. The primary finding is that interaction is a significant factor in achieving students' satisfaction. This result is important for teachers who want to focus on enhancing students' satisfaction by considering their resilience. The effect of resilience on self-efficacy can be utilized in students' academic life and mentoring activities. Regardless of whether resilience is viewed as an outcome or a process, it is a significant skill. university students should develop their resilience to adjust to continuous changes. It can lead them coping with work, marriage, and parenthood.

This research should be replicated with a more varied group of people. Only online students from the postgraduate program were studied in this study. Thus, it would be more meaningful to include other online student groups from various fields and see if students' satisfaction remains the most important predictor of academic success in online environments. In addition, due to the small number of online students recruited in this study, future researchers should employ students from multiple semesters to increase the number of student answers.

\section{References}

Alqurashi, E. (2019). Predicting student satisfaction and perceived learning within online learning environments. Distance Education, 40(1), 133-148. https://doi.org/https://doi.org/10.1080/015 87919.2018.1553562.

Bandura, A. (1977). Self-efficacy: Toward a Unifying Theory of Behavioral Change. Psychological Review, 84(2), 191-215. https://doi.org/10.1007/978-3-319-75361-4

Bower, M., \& Sturman, D. (2015). What are the educational affordances of wearable technologies? Computers and Education, 88 , 343-353. https://doi.org/10.1016/j.compedu.2015.07 .013

Buelow, J. R., Barry, T., \& Rich, L. E. (2018). Supporting learning engagement with online students. Online Learning Journal, 22(4), 313-340. https://doi.org/10.24059/olj.v22i4.1384

Creswell, J. W. (2009). Research Design: Qualitative, Quantitative, and Mixed Methods Approaches. (M. P. Scott, Ed.). University of Nebraska-Lincoln: SAGE Publications, Inc.

de Paepe, L., Zhu, C., \& Depryck, K. (2018). Dropout, retention, satisfaction and attainment of online learners of Dutch in adult education. International Journal on ELearning: Corporate, Government, Healthcare, and Higher Education, 17(3), 303-323. 
Doo, M. Y., \& Bonk, C. J. (2020). The effects of selfefficacy, self-regulation and social presence on learning engagement in a large university class using flipped Learning. Journal of Computer Assisted Learning, 36(6), 9971010. https://doi.org/10.1111/jcal.12455

Gray, J. A., \& Diloreto, M. (2016). The Effects of Student Engagement, Student Satisfaction, and Perceived Learning in Online Learning Environments This. NCPEA International Journal of Educational Leadership Preparation, 11(1), 98-119.

Hong, J. C., Hwang, M. Y., Tai, K. H., \& Lin, P. H. (2017). Intrinsic motivation of Chinese learning in predicting online learning selfefficacy and flow experience relevant to students' learning progress. Computer Assisted Language Learning, 30(6), 552574.

https://doi.org/10.1080/09588221.2017.13 29215

Jiwa, R. N. F., Tanduklangi, A., \& Sailan, Z. (2017). Cognitive Style, Attitude, and Self Efficacy as Predictors of Student Success in EFL Online Courses at Halu Oleo University. ... of Language Education and Educational ..., 2(2). Retrieved from http://ojs.uho.ac.id/index.php/JLEET/article /view/6695

Kalaycl, Ş. (2009). SPSS Applied multivariate statistical techniques. Ankara: Asil Publishing.

Kreth, Q., Spirou, M. E., Budenstein, S., \& Melkers, J. (2019). How prior experience and selfefficacy shape graduate student perceptions of an online learning environment in computing. Computer Science Education, 29(4), 357-381. https://doi.org/10.1080/08993408.2019.16 01459
Landrum, B. (2020). Examining students' confidence to learn online, self-regulation skills and perceptions of satisfaction and usefulness of online classes. Online Learning Journal, 24(3), 128-146. https://doi.org/10.24059/olj.v24i3.2066

Lin, S., Hu, H. C., \& Chiu, C. K. (2020). Training Practices of Self-efficacy on Critical Thinking Skills and Literacy: Importance-Performance Matrix Analysis. Eurasia Journal of Mathematics, Science and Technology Education, 16(1), 1-10. https://doi.org/10.29333/ejmste/112202

Malmberg, J., Järvelä, S., Järvenoja, H., \& Panadero, E. (2015). Promoting socially shared regulation of learning in CSCL: Progress of socially shared regulation among high- and low-performing groups. Computers in Human Behavior, 52, 562-572. https://doi.org/10.1016/j.chb.2015.03.082

Morgan, H. (2019). Online Instruction and Virtual Schools for Middle and High School Students: Twenty-First-Century Fads or Progressive Teaching Methods for Today's Pupils? The Clearing House, 72-76. https://doi.org/10.1080/00098655.2015.10 07909

Muzammil, M., Sutawijaya, A., \& Harsasi, M. (2020). Investigating Student Satisfaction in Online Learning: the Role of Student Interaction and Engagement in Distance Learning University. Turkish Online Journal of Distance Education, (July), 88-96. https://doi.org/10.17718/tojde.770928

O'Flaherty, J., \& Phillips, C. (2015). The use of flipped classrooms in higher education: A scoping review. Internet and Higher Education, 25, 85-95. https://doi.org/10.1016/j.iheduc.2015.02.0 02 
Panadero, E., \& Alonso-tapia, J. (2014). How do students self- regulate? Review of Zimmerman's cyclical model of selfregulated learning. Anales de Psicología, 30, 450-462.

Skinner, E., \& Pitzer, J. (2012). Developmental dynamics of student engagement, coping, and everyday resilience. (The handbo). New York: NY: Springer Science.

Strawser, M., Kercsmar, S., \& Pennell, M. (2017). A Blended Basic Course Examination of Communication Apprehension and SelfEfficacy: A Comparative Analysis. Basic Communication Course Annual, 29(1), 6.

Wolverton, C. C., Guidry Hollier, B. N., \& Lanier, P. A. (2020). The impact of computer self efficacy on student engagement and group satisfaction in online business courses.
Electronic Journal of E-Learning, 18(2), 175188.

https://doi.org/10.34190/EJEL.20.18.2.006

Yu, X., Wang, C. X., \& Spector, J. M. (2020). Factors that impact social networking in online selfregulated learning activities. Educational Technology Research and Development, 68(6),

3077-3095. https://doi.org/10.1007/s11423-02009843-9

Zimmerman, W. A., \& Kulikowich, J. M. (2016). Online Learning Self-Efficacy in Students With and Without Online Learning Experience. American Journal of Distance Education, 30(3), 180-191. https://doi.org/10.1080/08923647.2016.11 93801 
Putu Dinia Suryandani, Made Hery Santosa 